DOI: https://doi.org/10.47405/mjssh.v6i6.813

\begin{tabular}{|c|c|}
\hline$\sqrt{10}$ & Malaysian Journal of Social Sciences and Humanities (MJSSH) \\
\hline $\begin{array}{l}\text { Malaysian Journal of } \\
\text { socai sciences and }\end{array}$ & Volume 6, Issue 6, June 2021 \\
\hline (MJ-ssH) & e-ISSN : 2504-8562 \\
\hline & $\begin{array}{l}\text { Journal home page: } \\
\text { www.msocialsciences.com }\end{array}$ \\
\hline
\end{tabular}

\title{
Labour Productivity Spillovers from Foreign Direct Investment: Evidence from Malaysian Industry Level Panel Data by Labour Skills Composition
}

\author{
Norhanishah Mohamad Yunus ${ }^{1}$ \\ ${ }^{1}$ School of Distance Education, Universiti Sains Malaysia (USM)
}

Correspondence: Norhanishah Mohamad Yunus (norhanishah@usm.my)

\begin{abstract}
This study adds to the literature by examining both technology and knowledge spillover effects of foreign direct investment (FDI) according to skill composition and also by country spillovers in Malaysian medium-high industry, which raises the question of the real benefits produced by both spillovers that Malaysia can reap from the presence of FDI in enhancing the labour productivity. Using the seemingly unrelated regression (SUR) estimator to estimate labour productivity function by skill composition, the results reported that the presence of Japanese, Singaporean and the United States MNCs are statistically significant in influencing the productivity of high and medium-skilled workers from both technology and knowledge spillover effects during the period of 2000 to 2018. Conversely, the analysis indicated that both Chinese and Taiwanese MNCs significantly increase the low-skilled labour productivity. An interesting finding was discovered, that the negative association between knowledge spillovers and labour productivity across the skills draws the attention for the role of local firms as recipients of FDIs depends not only on their absorptive capacity but also on their strategic decisions regarding search direction and motivational disposition to absorb external knowledge. These issues need to be investigated further to understand how local firms may increase their chances of benefitting from $\mathrm{MNC}$ presence.
\end{abstract}

Keywords: spillover effects, foreign direct investment, labour productivity, technology spillovers, knowledge spillovers

\section{Introduction}

Empirically, multinational companies (MNCs) are a powerful vehicle in transferring capital and managerial and technical knowledge across nations (Wenchuan Liu, 2004; Yunus, 2020). Even though the importance of FDI as a source of technology and knowledge has been widely accepted, its impact on skill development is still unknown (Araújo, Bogliacino, \&Vivarelli,2009; Yunus\&Masron,2020). Similarly, numerous studies supporting that MNCs tend to employ more skilled workers, pay higher salaries and spend more on training than their domestic enterprise counterparts (Ramstetter, 2014). This explains their higher productivity and the potential for increasing capital inflows, raising local employment, and bringing technological and managerial expertise to the host economy (Perri \& Peruffo, 2016).

Despite its relevance, there is limited consolidation of the FDI knowledge spillover research in the labour productivity in the developing countries, including Malaysia. Most previous research had focused mainly on how local firms may gain from the presence of MNC subsidiaries on "technology" 
effects rather than "knowledge" effects from the presence of FDI in the manufacturing (Yunus\&Masron,2020, Perri \& Peruffo, 2016). Both spillover effects need to be investigated to implement policies that directly attract and promote FDI to a greater extent in increasing the ability of the workforce to absorb both spillover effects. The investigation is needed because technology adoption and interaction with new technologies are not always easy to transfer and can even produce rejection, hostility, and alienation (Munteanu, 2015).

In this paper, the present study aims to contribute to the existing studies in two ways: First, this paper draws attention to study both spillover effects by country spillovers in the medium-high industry (MIDA,2019) ${ }^{1}$. This is because Malaysia continued to be the investment destination for high-value manufacturing and global services in Asia and received the highest MNCs from Singapore, Hong Kong, the United States of America and Japan. However, the spillover effects from different investor countries in improving Malaysian labour productivity remained ambiguous in the medium-high industry even though foreign firms produced most manufactured exports (Yunus\& Wahob, 2021, MIDA, 2019). For example, the electronics industry contributes more than half the exports of manufactured goods comprised mostly of foreign-owned multinationals (Noor, 2000).

Secondly, this paper aims to focus on both spillover effects according to skill composition in the medium- high industry. This is in line with the motivation to examine which spillover effects are more assimilated and absorbed by high-, medium- and low-skilled workers, and the relationship between employment and FDI is seen to be not highly substantial (Yunus, Said, \& Azman-Saini, 2015; Yunus\& Wahob, 2021). In this paper, the present study also focuses on separating the labour productivity function by skill composition to identify possible differences in relevant relationships, rather than only focusing on the relative effects as the capital and skill complementarities may be more obvious for skilled workers than for unskilled workers (Yunus et al., 2015). Less evident is known how FDI spillovers affect the labour productivity of medium-low skilled workers in the high- medium industry (Yunus\& Masron, 2020).

The outline for the rest of this study is as follows. Section 2 provides a review of the literature. In Section 3, this study details the methodology. Section 4 then outlines the result and discussion. Finally, in Section 5, the present study closes the paper with a conclusion and policy implications.

\section{Literature Review}

Theoretically, the importance of FDI from FDI is undeniable, especially in developing countries, including technology and knowledge to the host country. According to the AK growth model developed by Harrod (1939) and Domar (1946) and further developed by Frankel (1962) and Romer and Frankel (1999) explained that a marginal decline in profits might not accompany capital accumulation from FDI. Profits of domestic enterprises may increase due to external factors created from the presence of FDI, such as technology, new management techniques and the impact of knowledge sharing. Therefore, the AK model emphasises that countries should continue to attract FDI inflows into the industry as more capital can be obtained from issuing stocks, and labour productivity can also be increased. In other words, the influx of FDI into enterprises will enable firms to acquire advanced administrative technologies that can be adopted to increase labour productivity, thereby contributing to the country's short -term and long -term economic development.

The term "spillovers" implies the positive interrelations between four effect channels. Four main channels of FDI spillovers, which are: competition, linkages, skills and imitation. As an implication,

\footnotetext{
1 The statistics show that the number of MNCs inflows into Malaysian E\&E was reported higher than other manufacturing industries. The bulk of FDI was concentrated in the E\&E products industry (RM21.79 billion, over double that of 2018), followed by paper, printing and publishing (RM9.69 billion, nearly double 2018's figure of RM4.99 billion), non-metallic mineral products, machinery and equipment (M\&E) (RM2.88 billion), chemical and chemical products (RM2.65 billion), scientific and measuring equipment (RM2.41 billion), transport technology (RM1.55 billion), and food manufacturing (RM1.31 billion).
} 
the total spillovers created by FDI was assumed to depend on the absorption capacity. It is argued that the larger the technology and human capital gap between the domestic and foreign firms, the less likely the domestic firms can exploit the potential of spillovers (Cohen and Levinthal,1989). Girma \& Görg (2005) showed the productivity benefit from FDI increases with absorptive capacity until reaching a threshold level, which would make it less pronounced.

Empirical evidence provides mixed results concerning the spillover effects of FDI. For example, using the U.K. plant-level data, Girma, Greenaway and Wakelin (2001) found that local firms that are 'technologically comparable' to foreign firms enjoy positive spillover. Haskel, Pereira and Slaughter (2007), using the same microdata exerted that plants further away from the technology frontier gain most from foreign presence in their sector (Findlay,1978). On the other hand, several studies find positive horizontal spillovers in more developed economies, such as the UK (e.g., Haskel et al. (2007), and the US (e.g., Keller and Yeaple, 2003). Other studies found the negative effects of FDI spillover effects: (e.g., studies of Morocco by Haddad and Harrison, 1993; Venezuela by Aitken and Harrison, 1999; Bulgaria and Romania by Konings, 2001; Russia by Yudaeva et al., 2003; the Czech Republic by Kosova, 2010). Meanwhile, Abraham et al. (2006) found no relationship between the gap and spillovers in China. The findings may differ because of different measures in that some studies used labour productivity and others used total factor productivity. They may also differ because of the methodology applied in the study. Hence, it may be necessary to consider certain threshold values in the estimation results (Girma,2005).

Concerning the results of studies of the impact of FDI spillover on employee productivity itself, until recently, such evidence remained widespread (e.g ., Blomstrom \& Persson, 1983; Blomstrom \& Wolff, 1994; Yunus \& Masron, 2020). Numerous FDI studies remain focused on Total Factor Productivity and skilled labour demand (Driffield, Love, \& Taylor, 2009; Elia, Mariotti, \& Piscitello, 2009; Liu, Agbola, \& Dzator, 2016; Yunus. et al., 2015). According to Liu et al. (2001), the positive effects of foreign direct investment on the labour productivity of the hosting industry are generally achieved through the formation of technology, management skills and techniques, and the impact of capital and spillover on local firms. Their study of 41 subsectors of China's electronics industry showed that the benefits of FDI depend on the technological capabilities of local firms, and to get more benefits from FDI, domestic firms must have greater technological capabilities.

A recent study by Wang and $\mathrm{Mu}$ (2012) used data covering 41 developing countries from 2005 to 2008 to assess how technological spillovers from the US influence labour productivity in the selected developing countries. The study found that the relationship between technological spillovers and labour productivity in developing countries are highly sensitive to model specification and estimation techniques. The simple pooled data estimations revealed a clear relation between technological spillovers and labour productivity, while more complex models such as dynamic panel data models failed in this task. The result from their analysis showed that only import has a significant impact on labour productivity. Meanwhile, Buckley et al. (2007) empirically exploring the effect of FDI inflows on the aggregate labour productivity of China's automotive industry. They applied two statistical models: pooled ordinary least squares model (POLS) and fixed effects model (FES), to estimate the influence of foreign direct investment on aggregate labour productivity in the industry. They found that inward FDI plays a positive and significant role in increasing industrial productivity, implying that the government should continue to encourage inward investment. The results also suggested that efforts to increase the capital intensity and average firm size in the industry will also improve labour productivity.

Even though the knowledge spillovers effects of FDI have been widely debated in the literature, there were few empirical studies on knowledge spillovers as a main channel of FDI transfer, and it remains focused on the developed countries and focusing on domestic firms performance. Only a few studies draw attention to study the knowledge spillover of FDI as a channel for increasing domestic firms' labour productivity. For instance, Mebratie \& Bedi (2013) studied the African firm by using twoperiod (2003 and 2007) firm-level panel data from South Africa to examine the impact of FDI on labour productivity. They also examined the interaction between foreign firm ownership and the broad-based black economic empowerment act (BB-BEE) on labour productivity. Regardless of the 
empirical specification, they found no spillover effects and no evidence that foreign firms' greater degree of BEE compliance influences labour productivity. Feinberg and Majumdar (2001) examined whether knowledge spillovers from MNCs' local R\&D activities benefit domestic firms in the Indian pharmaceutical industry from 1980-1994. They showed that the only significant R\&D spillovers in the Indian pharmaceutical sector were between MNCs and each other. This study stressed that the absence of a government R\&D development policy is a major obstacle for MNCs to transfer knowledge in the Indian pharmaceutical industry.

In the context of Malaysia, to date, there are no studies simultaneously focusing on the spillover effects of FDI as classified by specific investor countries and by skill composition. A recent study by Yunus and Wahob (2021) investigated the "technology" and "knowledge" spillover effects of FDI on labour productivity by country spillovers. They found no positive spillover of technological effects in the medium-high industries from all investor countries. Based on the main investor countries, local workers have assimilated and absorbed higher knowledge from the Japanese firms, followed by American and Singaporean firms in the medium-high industries. Meanwhile, Yunus and Masron (2020) study both spillover effects of FDI by skill composition itself using the current 2-digit levels of panel data set from 13 manufacturing industries from 2000 to 2017. Applying the ordinary least square (OLS) estimator with a robust standard error, the results reported that the "technology effects" measured by the number of FDI companies are greater compared to MNCS' capital investments and "knowledge" effects in increasing labour productivity. However, the diffusion of FDI knowledge via "learning effects" showed a significant negative relationship with labour productivity across all skill levels. Regarding the spillover effects by country's spillovers in Malaysia, Masron and Hassan (2016) studied the spillover effect of US FDI on the Malaysian economy. Applying the seemingly unrelated regression (SUR) method, this study observes that there is no guarantee that FDI inflows into various sectors within the manufacturing industry will generate positive externalities.

Hence, to bridge the gaps in the literature, this study aims to relook at the spillover effects of FDI from both technological and knowledge angles concerning country spillovers and by skill composition on labour productivity and its link to the other explanatory variables, which are not fully explored according to industry classification in the manufacturing industries. The present study includes the effects of human capital and link with firm size, R\&D variables and direct domestic investors on labour productivity function due to the role these variables in increasing the labour productivity in this empirical research are still concluded ambiguously (Benhabib and Spiegel, 1994, Frantzen,2000; Le et al., 2019, Yunus et, al, 2014).

\section{Methodology}

\section{Data Description and Scope of Study}

The main data sources used in this study are gathered from the Department of Statistics Malaysia (DOSM) and Malaysian Industry and Development Authority (MIDA) based on a manufacturing survey on industries. The variables gathered from DOS are total employment, production and nonproduction workers, Research and Development (R\&D) investment, and cost of training (TRAIN). The data gathered from MIDA comprise three variables, namely the share of foreign capital investment (TECH), number of FDI companies (NF), and share of local employees working in the foreign manufacturing industry (EMP).

Following Liu et al. (2001), the present study measures the labour productivity by value-added per worker to the number of average annual employees in each sub-sector of the manufacturing industry. The advantage of this measurement reflects the combined effects of changes in capital inputs, intermediate inputs, and overall productivity, without leaving out any direct effects of technical change, whether such effects are embodied or disembodied.

In this study, the employment refers to the number of paid employees (full-time) per year and it is split into high-, medium- and low-skilled workers. The high-skilled workers in this study, namely the 
legislators, managers, professional and executives, technician, and associate professionals. Mediumskilled workers refer to the Clerical and related occupations. Low-skilled workers include Elementary occupations, Plant \& machine operators and assemblers.

Technology spillover effects of FDI are measured by foreign capital investment (TECH) as a channel of spillover effects through "technology" (Bwalya, 2006; Bandick \& Hansson, 2009). In this study, foreign capital investment is a share of foreign capital investment by investor countries from total foreign investment in a year. Meanwhile, the knowledge effects (EMP) from FDI spillovers are measured as a share of local employees working in the foreign firms to total employment (parents and affiliates) in each manufacturing industry as a proxy for ease of access to FDI's knowledge (Blonigen \& Slaughter, 2001; Figini \& Görg, 1999; Girma et al., 2001).

This study focuses on four selected medium-high manufacturing industries at the 2-digit level. These industries are: Electronics and Electrical (E\&E), Chemical, Machinery and Equipment (ME), and Transport Equipment (TE). The present study focuses on the medium-high industry due to technology spillovers that have been associated with the manufacturing sector for a long time. These industries are supported by private investment, and the regulatory framework is changed to attract both domestic and foreign investments, thus potentially contributing to economic growth and labour productivity (EPU, 2016).) In addition, more MNCs concentrated their activity on this sector rather than the low receiving industry, i.e. medium-low and low-technology industry.

This study covers the period 2000-2018 as the amount of FDI into the Malaysian manufacturing industry increased sharply during that period. The time frame chosen in this study is also in line with this study which seeks to examine how the impact of FDI inflows by major investor countries affects the productivity of skilled, medium and low-skilled workers. During this period, the number of local jobs employed and engaged in activities in MNC companies has increased, enabling us to measure whether Malaysian workers can acquire knowledge gained through training from MNCs and, in turn, contribute to higher employee productivity (Yunus, 2014).

\section{Empirical Model}

The model specification by Liu, Parker, Vaidya, and Wei (2001) is applied to explore the FDI spillover effects and other possible variables factors that influence labour productivity. The basic model for labour productivity of skilled, medium- and low-skilled respectively can be expressed as follows:

$$
\begin{aligned}
& \ln H S_{i t=} \ln A_{i t}+B_{1} \ln \left(\frac{K}{L}\right)_{i t}+B_{2} \ln F D I_{i t c}+B_{3} \ln E M P_{i t c}+B_{4} \ln X_{i t}+\varepsilon_{i t} \\
& \ln M S_{i t=} \ln A_{i t}+B_{1} \ln \left(\frac{K}{L}\right)_{i t}+B_{2} \ln F D I_{i t c}+B_{3} \ln E M P_{i t c}+B_{4} \ln X_{i t}+\varepsilon_{i t} \\
& \ln L S_{i t=} \ln A_{i t}+B_{1} \ln \left(\frac{K}{L}\right)_{i t}+B_{2} \ln F D I_{i t c}+B_{3} \ln E M P_{i t c}+B_{4} \ln X_{i t}+\varepsilon_{i t}
\end{aligned}
$$

where $i$ and $t$ are the industry and time index, respectively. $i$ is an index of the industry including Electronics and Electrical (E\&E), Chemical, Machinery and Equipment, and Transport Equipment. $t$ is the time index. $c$ is an index of the country's spillovers (Japan, China, Singapore, Taiwan and the United States). $Y$ refers to labour productivity per value-added for high-skilled $(H S)$, medium-skilled $(M S)$ and low-skilled $(L S)$ workers respectively. $\frac{K}{L}$ the ratio of capital to worker (K/L) or capital intensity is approximated by gross investments in fixed capital per worker (Corvers, 1997). FDI is the share of foreign capital investment from total investment to represent FDI spillovers via "technology effects". EMPT is the share of local employees working in the multinational companies (EMP), which consists of Japan $\left(E M P_{J}\right)$, Singapore $\left(E M P_{S}\right)$, China $\left(E M P_{C}\right)$, Taiwan $\left(E M P_{T}\right)$, and the United States $\left(E M P_{U S}\right) . \mathrm{X}$ represents other factors commonly considered in discussing labour productivity, namely TRAIN (cost of training per employee), $R D$ (R\&D investment), $D S$ (share of domestic investment from local investors), and $F S$ (firm size). $\varepsilon_{i t}$ is an error term that captures the time varying firm-specific productivity shocks. 
With the limitation in panel data at the 2-digit industry level (in our case, we have 76 observations), the present study employs a seemingly unrelated regression (SUR) estimator, which is one of the panel data estimation methods (Zellner,1962,1963). ${ }^{2}$ In this study's case, SUR is the best method of estimating panel data models as the number of industry $(\mathrm{N})=4$ industries are long than year $(\mathrm{T})=19$. When estimating the SUR model, it is important to highlight that the data need to be arranged as a time series (not a panel) with different variables listed separately. In the basic SUR model, the errors are assumed to be homoscedastic and linearly independent within each equation. By applying this method, the outcome of this analysis is perhaps useful in providing a preliminary picture of the levels of Malaysian skills required to absorb the spillover effects of FDI. We can then identify which spillover effects of FDI have more influence on the Malaysian labour productivity by considering the error terms' correlations across equations leads to better predictions of future values of the dependent variables. The SUR estimator provides the lowest standard errors of the estimated parameters and, thus, the highest precision of the estimates.

\section{Result}

In this section, this study presents the results of labour productivity by skill composition and by country's spillovers as an outcome of spillover effects from FDI in the medium-high-industry as shown in Table 1. The present study begins to discuss the labour productivity analysis by looking at "technology" and by country's spillovers in the medium-high industry across workers' skills. Model (1) in Table 1 reveals spillover effects of technology from Japanese statistically significant influence the labour productivity of high-skilled and medium-skilled at $\alpha=5 \%$ with a value of 0.048 and 0.037 , respectively. This means that capital investment from FDI can be accessed by firm access firms because the positive spillover effects have had a significant impact on the labour productivity growth of medium-high- skilled labour in the manufacturing medium-high industry.

A similar result reported that the knowledge spillover effects from Japanese firms could be absorbed and applied only by the high and medium-skilled workers working in the Japanese MNCs. The results in this study found that either technology or knowledge effects spillovers by Japanese companies are statistically insignificant to increase the low-skilled labour productivity. The results of this study show that there is a change in the demand for labour that involves the redistribution of labour between sectors in Malaysia, especially where the transition of low-skilled labour from high to low productivity sectors based on their ability to access the overflow of FDI technology (Yunus \& Masron 2020). The result also suggests hiring activities where employees are likely to move into the new establishments. This is especially evident when skill requirements involve those that are highly transferable between different industries.

\footnotetext{
${ }^{2}$ Several model selection tests were tested such as Ordinary Least Square (OLS), Generalized Method of Moments (GMM), Random Effect and Fixed Effect Model before the present study select SUR as a best method to analyse the results in this study, but we could not yield the best results. It is well-known that ordinary least squares which ignore the correlation patterns across blocks may yield inefficient estimators. For GMM, the condition to perform GMM is that the number of observations (N) must be greater than $T$. For Random Effect estimator, we cannot establish small sample properties. For fixed-effects models, even though it is widely recognised as the convenient and powerful tools for longitudinal data analysis, there are limitations in these models. The primary limitation is unobserved heterogeneity due to unmeasured characteristics that do vary over time. The problem is that fixed-effects coefficients are biased in a conservative fashion when the data are characterised by a small number of panels (Allison, 2009). This study also found that the standard errors for fixed effects coefficients are often larger than those for other methods, especially when the predictor variable has little variation over time.
} 
DOI: https://doi.org/10.47405/mjssh.v6i6.813

Table 1: Result of Seemingly Unrelated Regression (SUR)-Analysis by Skill Composition in the Medium-high Industry, 2000-2018

\begin{tabular}{|c|c|c|c|}
\hline $\begin{array}{l}\text { Independent Variables } \\
\text { Labour Productivity }\end{array}$ & $\begin{array}{c}\text { Model (1) } \\
\text { High-Skilled }\end{array}$ & $\begin{array}{c}\text { Model (2) } \\
\text { Medium-Skilled }\end{array}$ & $\begin{array}{c}\text { Model (3) } \\
\text { Low -Skilled }\end{array}$ \\
\hline Capital/labour & $0.165(0.0435)^{* *}$ & $0.096(0.054)$ & $0.1840 .015)^{* *}$ \\
\hline \multicolumn{4}{|c|}{ Technology Spillover Effects by Investor Countries } \\
\hline Japan & $0.048(0.023) * *$ & $0.037(0.028)^{* *}$ & $0.0049(0.027)$ \\
\hline United of States & $0.024(0.019)^{*}$ & $0.018(0.023)^{*}$ & $0.0044(0.0227)$ \\
\hline Singapore & $0.033(0.013)^{*}$ & $0.016(0.021)^{*}$ & $-0.006(0.036)$ \\
\hline Taiwan & $0.071(0.014)$ & $0.033(0.017)^{* *}$ & $0.024(0.016)^{*}$ \\
\hline China & $0.019(0.022)$ & $-0.0186(0.0277)$ & $0.022(0.026)^{*}$ \\
\hline \multicolumn{4}{|c|}{ Knowledge Spillover Effects (No. of Local Employment in the MNCs by Investor Countries } \\
\hline Japan & $0.067(0.029) * *$ & $0.066(0.037)^{* *}$ & $-0.039(0.035)$ \\
\hline United of States & $0.004(0.023)^{*}$ & $-0.0816(0.028)^{*}$ & $-0.017(0.027)$ \\
\hline Singapore & $0.021(0.0431)^{*}$ & $-0.028(0.054)^{* *}$ & $0.0152(0.053)^{*}$ \\
\hline Taiwan & $-0.003(0.0247)$ & $0.108(0.031)^{* *}$ & $0.051(0.030)^{*}$ \\
\hline China & $-0.023(0.029)$ & $-0.061(0.036)$ & $-0.0281(0.035)$ \\
\hline \multicolumn{4}{|l|}{ Control Variables } \\
\hline Share of Degree & $0.155(0.151)$ & $0.440(0.044) * * *$ & $0.582(0.184) * * *$ \\
\hline Share of diploma & $0.034(0.114)$ & $0.177(0.143)$ & $0.550(0.019)^{* * *}$ \\
\hline $\begin{array}{l}\text { Share of Middle Certificate } \\
\text { of Education/Vocational } \\
(\mathrm{MCE} / \mathrm{MCEV})\end{array}$ & $0.017(0.068)$ & $0.025(0.085)$ & $0.099(0.084)$ \\
\hline Training Cost & $0.076(0.042) *$ & $0.086(0.052) *$ & $0.142(0.051)^{* * *}$ \\
\hline R\&D Expenditure & $\begin{array}{l}-0.006 \\
(0.0237)^{* *}\end{array}$ & $-0.122(0.029)^{* * *}$ & $-0.131(0.029)^{* * *}$ \\
\hline Firm Size & $\begin{array}{l}0.213(0.059) \\
* * *\end{array}$ & $0.325(0.074)^{* *}$ & $0.285(0.072)^{* * *}$ \\
\hline Domestic investment & $0.069(0.040)^{*}$ & $0.107(0.0509)^{* *}$ & $0.0581(0.049)^{* *}$ \\
\hline ICT expenses & $\begin{array}{l}0.117(0.035) \\
* * *\end{array}$ & $0.083(0.044)^{* * *}$ & $0.184(0.042)^{* * *}$ \\
\hline Constant & $8.903(0.039)^{*}$ & $3.668(0.051)^{* * *}$ & $1.242(0.234)^{* *}$ \\
\hline Observations & 76 & 76 & 76 \\
\hline R-squared & 0.886 & 0.833 & 0.915 \\
\hline
\end{tabular}

Notes: All variables are transformed into natural log. Bootstrapped standard errors for SUR in parentheses. $* * * \mathrm{p}<0.01, * * \mathrm{p}<0.05, * \mathrm{p}<0.1$.

The results present in Table 1 also shown the similar patterns of Unites States and Singaporean MNCS about both technology and knowledge spillover effects. This study found the presence of "technology" and knowledge spillovers by American and Singaporean MNCs in model (1) and model (2) that appear in influencing labour productivity for high-skilled -and medium-skilled in the medium-high industry. This result suggested that the positive findings concerning both spillover effects of FDI on high and medium-skilled categories can be attributed to the capacity of workers to absorb both technology and knowledge transfers from MNCs. These results suggest that MNCs may give Malaysian staff training for managerial, skilled and semi-skilled workers and give them opportunities in international travel and visits to MNCS' headquarters or affiliated companies, exposing them to new learning curves. All such activities are contributing to the value-added of the labour productivity of medium-high skilled workers. This is in line with the demand in the medium-high industry requires manpower, especially among senior executives, managers, and senior managers, to improve business operations, including human resource management, information technology, maintenance, supply and distribution, health and safety, product development and logistics.

This study also suggests that both MNCs in Malaysia may have successfully conducted in-house training program, both formal and informal. In this way, MNCs have helped set minimum standards of 
employee efficiency and productivity. Previous studies support that the presence of MNCs in Malaysia is to provide domestic enterprises access to cutting -edge technology through subcontracting, spin-off company creation, Original equipment manufacturer(OEMs) and training activities and the advantages of world allies and their location (Noor, 2000). However, for the knowledge spillover effects, a negative sign appeared for medium-skilled workers indicating the absorbency ability of medium-skilled workers to assimilate and adapt knowledge effect through learning effect brought by US and Singapore MNC in this industry even coefficient less than 0.10 .

Next, attention is shifted to analyse the FDI inflows from the major investors used in this study, i.e., Taiwan. The results of this study report that the spillover effect of Taiwanese MNCs can only be applied in influencing low -skilled productivity either from the influence of technology or knowledge, as shown in model (3). The results showed that the influence of technology and knowledge from Taiwanese firms could increase the productivity of low -skilled workers at $\alpha=1 \%$ with values of 0.024 and 0.051 , respectively. A clear explanation for the results is that the local input and subcontracting activities involved are particularly labour intensive and low value-added activities that reflect the technological capabilities of local suppliers (Noor 2000). While this explanation seems interesting, it is impossible to determine why the spillover effects from Taiwan only affect the productivity of low -skilled workers with the data used in this study.

For Chinese investor, surprisingly to note that both spillover effects from this country are insignificant to increase all level of workers' skill (except the technology effects for low-skilled workers). The results indicated that a $1 \%$ increase in the technology effects brought from Chinese MNCs would increase the low-skilled labour productivity by $2.2 \%$. The possible reason can be associated with the results found in this study because local SMEs have had difficulties adapting to structural market changes of Chinese MNCs toward high value-added activity. Hence, the Chinese MNCs remained to operate on that employed the low-skilled workers. The mismatch between the MNCs demand and the skills provided by the medium-high skilled workers in the and local SMEs will lead the MNCs to be slow to invest in manufacturing upgrades and ultimately increase workers' labour productivity. The current situation of local SMEs in some industry branches has become critical with low-tech manufacturing activities of MNCs moving to lower-cost locations such as China and Vietnam. Also, the constraints in the supply of workers that occur also reflect the constraints where most of the job vacancies that exist require certain types of skills can be associated with the finding found in this study.

For other explanatory variables, overall, the results showed that all explanatory variable selected in this study are significantly influencing to increase productivity across the skills. However, interesting to note that this study found that the coefficient value of firm size gives the most significant effects compared to other explanatory variables because the argument as to whether the size of firm influences technological activity has attracted much attention. The results found in contributing to the additional literature supported the study found by Cohen and Klepper (1996) because the relationship between firm size and $R \& D$, however, is still ambiguous. The study concludes that the size of a firm is significant in assisting the technological spillovers from FDI can be absorbed by the workers, which contribute to higher labour productivity. This study also supported the previous study, i.e., Sasidharan \& Kathuria (2011), which argued that large firms (i.g: medium high technology industry in this study) are better able to conduct technological activities compared to small firms. However, this study emphasises that the size and significance of these differentials often varied depending on the industry and sample examined and the estimation technique used.

\section{Conclusion}

In this section, three main conclusions can be derived from the results found in this study. First, the study found that spillover effects of FDI either from technology or knowledge from Japanese, Singaporean and the Unites States MNCs are statistically significant in skill upgrading and thus increase both high and medium skilled workers in the medium-high industry. Secondly, this study showed that the Taiwanese MNCs only contribute to increasing the low-skilled workers from both 
technology and knowledge diffusions. Lastly, Chinese investors in the medium-high industry can only produce spillovers both their technology and knowledge effects of increasing the low-skilled workers' productivity. These results implying that the nature of manufacturing activity has been shifting from manual labour to programming, automation and smart machines required high and semi-skilled workers. Employees with low skill levels may tend to be restructured according to the skills possessed or replaced unless retrained in line with industry needs.

Even though the results in this study showed that technology effects have a greater magnitude than knowledge effects, but this study draws attention to the importance of knowledge skills or soft skills required among companies, including generic hard skills, competencies in language skills, knowledge in business law, legislative and regulatory awareness. Given that knowledge transfer and learning occur through firm interactions, this study considers industrial agglomeration as the important regional dimension that causes variation in a region's absorptive capability to gain from the environmental knowledge brought by FDI. This study draws attention to the importance of suppliers' role in MNCs has been dwindling, growth and innovation of SMEs have been lagged in keeping a parallel pace with MNCs. The government should encourage SMEs to invest in $R \& D$ and innovation to upgrade their activities and knowledge spillovers through the cluster effect.

Finally, it is important to note that different spillover effects between MNCs may be due to environmental changes caused by globalisation that have changed the context of technology transfer, suggesting necessary changes in the framework and approach in analysing the effectiveness of the technology transfer process. The study also found that the slow technology transfer by some MNCs was influenced by the lack of R\&D and local innovation system in local firms, low labour absorption capacity and partly attributed to the transferee institutional weaknesses. Different estimation techniques, types of data used as well as study duration, proxies used to measure spillover effects as well as theoretical models of FDI spillovers are often based on assumptions that are valid only under specific conditions will generate controversial findings between countries and even between economic sectors (Meyer and Sinani 2009).

Future research is recommended to expand the research by using the data of other investors such as the United Kingdom, Republic of Korea, Netherland, which are also active investor countries. In addition, this study can also be extended in the services sector. Therefore, a comparison in terms of variance of labour productivity results from various investor countries in the Malaysian economics sector can be made. Furthermore, other proxies in measuring the impact of technology and knowledge spillover from FDI can be further expanded in future research can be further expanded. The recommendations presented above can help the Malaysian government implement different policies according to their respective investors to drive FDI inflows as foreign firms from various countries use different technologies and management practices. The policy of attracting FDI can be carried out to increase the productivity of the Malaysian workforce and, most importantly, to ensure the transfer function of their FDI technology and knowledge to the workforce, which must be based on Key Performance Indicators (KPIs).

\section{Acknowledgement}

This work was supported by Universiti Sains Malaysia under the Short-Term Research Grant Scheme No. 304/PJJAUH/6315270.

\section{References (APA STYLE)}

Abraham, F., Konings, J., \& Slootmaekers, V. (2006). FDI spillovers, firm heterogeneity and degree of ownership: evidence from Chinese manufacturing. Unpublished Paper, Department of Economics, Catholic University of Leuven, November.

Aitken, B. J., \& Harrison, A. E. (1999). Do domestic firms benefit from direct foreign investment? Evidence from Venezuela. American Economic Review, 89(3), 605-618.

Allison, P. (2009). Fixed effects regression models. In Fixed Effects Regression Models. SAGE 
Publications, Inc. https://doi.org/10.4135/9781412993869

Araújo, B. C., Bogliacino, F., \& Vivarelli, M. (2009). The role of skill enhancing trade in Brazil:

Some evidence from micro data. Economic Research Papers, 97(10), 1- 22.

Benhabib, J., \& Spiegel, M. M. (1994). The role of human capital in economic development evidence from aggregate cross-country data. Journal of Monetary economics, 34(2), $\quad 143-173$.

Blomström, M., \& Persson, H. (1983). Foreign investment and spillover efficiency in an underdeveloped economy: Evidence from the Mexican manufacturing industry. World Development. https://doi.org/10.1016/0305-750X(83)90016-5

Blomström, M., \& Wolff, E. N. (1994). Multinational corporations and productivity convergence in Mexico. Convergence of productivity: Cross-national studies and historical evidence, 263-84.

Blonigen, B. A., \& Slaughter, M. J. (2001). Foreign-affiliate activity and US skill upgrading. Review of Economics and Statistics, 83(2), 362-376. Available at: https://doi.org/10.1162/00346530151143888

Buckley, P. J., Clegg, J., \& Wang, C. (2002). The Impact of Inward FDI on the Performance of Chinese Manufacturing Firms. Journal of International Business Studies, 33(4), 637-655. https://doi.org/10.1057/palgrave.jibs.8491037

Bwalya, S. M. (2006). Foreign direct investment and technology spillovers: Evidence from panel data analysis of manufacturing firms in Zambia. Journal of Development Economics, 81(2), 514-526. Available at: https://doi.org/10.1016/j.jdeveco.2005.06.011.

Cohen, W. M., \& Klepper, S. (1996). A reprise of size and R \& D. The Economic Journal, 106(437), 925-951.

Cohen, W. M., \& Levinthal, D. A. (1989). Innovation and learning: the two faces of R \& D. The Economic Journal, 99(397), 569-596.

Djulius, H. (2017). Foreign Direct Investment and Technology Transfer: Knowledge Spillover in the Manufacturing Sector in Indonesia. Global Business Review. https://doi.org/10.1177/0972150916666878

Domar, E. D. (1946). Capital expansion, rate of growth, and employment. Econometrica, Journal of the Econometric Society, 137-147.

Driffield, N., Love, J. H., \& Taylor, K. (2009). Productivity and labour demand effects of inward and outward foreign direct investment on uk industry. The Manchester School, 77(2), 171-203. https://doi.org/10.1111/j.1467-9957.2008.02093.x

Elia, S., Mariotti, I., \& Piscitello, L. (2009). The impact of outward FDI on the home country's labour demand and skill composition. International Business Review, 18(4), 357-372.

Feinberg, S. E., \& Majumdar, S. K. (2001). Technology spillovers from foreign direct investment in the Indian pharmaceutical industry. Journal of International Business Studies, 32(3), 421-437.

Figini, P., \& Görg, H. (1999). Multinational companies and wage inequality in the host country: The case of Ireland. Weltwirtschaftliches Archiv, 135(4), 594-612. Available at: https://doi.org/10.1007/BF02707386.

Findlay, R. (1978). Relative backwardness, direct foreign investment, and the transfer of technology: a simple dynamic model. The Quarterly Journal of Economics, 92(1), 1-16.

Frankel, M. (1962). The production function in allocation and growth: a synthesis. The American Economic Review, 996-1022.

Frankel, J. A., \& Romer, D. H. (1999). Does trade cause growth? American Economic Review, 89(3), 379-399.

Hair, Joseph, F., Rolph, E. A., Ronald, L. T., \& William, C. B. (1995). Multivariate data analysis. London: Prentice Hall.

Haskel, J. E., Pereira, S. C., \& Slaughter, M. J. (2007). Does inward foreign direct investment boost the productivity of domestic firms? The Review of Economics and Statistics, 89(3), 482-496.

Girma, S., \& Görg, H. (2005). Foreign Direct Investment, Spillovers and Absorptive Capacity: Evidence from Quantile Regressions. SSRN Electronic Journal. https://doi.org/10.2139/ssrn.410742

Girma, S., Greenaway, D., \& Wakelin, K. (2001). Who Benefits from Foreign Direct Investment in the UK? Scottish Journal of Political Economy, 48(2), 119-133. http://dx.doi.org/10.1111/14679485.00189

Gujarati, D. N., Porter, D. C., \& Gunasekar, S. (2012). Basic Econometrics. Tata McGraw-Hill Education. 
Haddad, M., \& Harrison, A. (1993). Are there positive spillovers from direct foreign investment? Journal of Development Economics, 42(1), 51-74. https://doi.org/10.1016/03043878(93)90072-U

Harrod, R. F. (1939). An essay in dynamic theory. The Economic Journal, 49(193), 14-33.

Jude, C. (2016). Technology spillovers from FDI. Evidence on the intensity of different spillover channels. The World Economy, 39(12), 1947-1973. https://doi.org/10.1111/twec.12335

Keller, W., \& Yeaple, S. R. (2003). Multinational enterprises, international trade, and productivity growth: firm-level evidence from the United States. The Review of Economics and Statistics, 9(4), 821-831.

Konings, J. (2001). The effects of foreign direct investment on domestic firms: Evidence from firmlevel panel data in emerging economies. Economics of Transition, 9(3), 619-633.

Kosova, R. (2010). Do foreign firms crowd out domestic firms? Evidence from the Czech Republic. The Review of Economics and Statistics, 92(4), 861-881.

Le, N. H., Duy, L. V. Q., \& Ngoc, B. H. (2019). Effects of foreign direct investment and human capital on labour productivity: Evidence from Vietnam. The Journal of Asian Finance, Economics, and Business, 6(3), 123-130.

Liu, W. S., Agbola, F. W., \& Dzator, J. A. (2016). The impact of FDI spillover effects on total factor productivity in the Chinese electronic industry: a panel data analysis. Journal of the Asia Pacific Economy, 21(2), 217-234. https://doi.org/10.1080/13547860.2015.1137473

Liu, X., Parker, D., Vaidya, K., \& Wei, Y. (2001). The impact of foreign direct investment on labour productivity in the Chinese electronics industry. International Business Review, 10(4), 421-439. https://doi.org/10.1016/S0969-5931(01)00024-5

Masron, T. A., \& Hassan, M. K. H. (2016). US foreign direct investment (FDI) and manufacturing sector in Malaysia. Asian Academy of Management Journal, 21(1), 89.

Mebratie, A. D., \& Bedi, A. S. (2013). Foreign direct investment, black economic empowerment and labour productivity in South Africa. The Journal of International Trade \& Economic Development, 22(1), 103-128. https://doi.org/10.1080/09638199.2013.745287

Meyer, K. E., \& Sinani, E. (2009). When and where does foreign direct investment generate positive spillovers? A meta-analysis. Journal of International Business Studies, 40(7), 1075-1094.

MIDA (2019). MIDA annual report: Investment performance 2019. Malaysia: Malaysia Investment Development Authority, Kuala Lumpur.

Munteanu, A.-C. (2015). Knowledge spillovers of FDI. Procedia Economics and Finance, 32, 10931099. https://doi.org/10.1016/S2212-5671(15)01573-7

Noor, A. H. M. (2000). Technological effort in developing countries: Multinational corporations in Malaysia. Jurnal Ekonomi Malaysia, 34, 39-58.

OECD. (2011). Review of innovation in Southeast Asia: Country profile of innovation in Malaysia. Malaysia: Organisation for Economic Co-operation and Development.

Perri, A., \& Peruffo, E. (2016). Knowledge Spillovers from FDI: A Critical Review from the International Business Perspective. International Journal of Management Reviews, 18(1), 3-27. https://doi.org/10.1111/ijmr.12054

Ramstetter, E. D. (2014). Wage Differentials between Foreign Multinationals and Local Plants and Worker Quality in Malaysian Manufacturing. Asian Development Review, 31(2), 55-76.

Sasidharan, S., \& Kathuria, V. (2011). Foreign direct investment and R\&D: Substitutes or complements-A case of Indian manufacturing after 1991 reforms. World Development, 39(7), 1226-1239.

Wang, Y., \& Mu, B. (2012). How technology spillovers from developed to developing countries influence labor productivity in developing countries.

Yudaeva, K., Kozlov, K., Melentieva, N., \& Ponomareva, N. (2003). Does foreign ownership matter? The Russian experience. Economics of transition, 11(3), 383-409.

Yunus, N. M. (2020). Determinants of Foreign Direct Investment: An Analysis on Policy Variables in the Malaysian Manufacturing Industry. International Journal of Asian Social Science, 10(12), 746-760. https://doi.org/10.18488/journal.1.2020.1012.746.760

Yunus, N. M., \& Hamid, F. S. (2019). Training, research and development, and spillover effects of foreign direct investment: A study on labour productivity in malaysian manufacturing industry. International Journal of Supply Chain Management, 8(3), 966-972.

Yunus, N. M., \& Masron, T. A. (2020). Spillover effects of inward foreign direct investment on labour 
productivity: An analysis on skill composition in manufacturing industry. International Journal of Asian Social Science, 10(10), 593-611. https://doi.org/10.18488/journal.1.2020.1010.593.611

Yunus, N. M., Said, R., \& Azman-Saini, W. N. W. (2015). Spillover effects of FDI and trade on demand for skilled labour in Malaysian manufacturing industries. Asian Academy of Management Journal, 20(2), 1-27.

Yunus, N. M., Said, R., \& Siong Hook, L. (2014). Do cost of training, education level and R\&D investment matter towards influencing labour productivity? Jurnal Ekonomi Malaysia, 48(1), $133-142$.

Yunus, N.M, Wahob, N.A. (2021). The technology and knowledge spillover effects of FDI on labour productivity. GATR Journal of Business and Economics Review, 5 (4), 51-58.

Zellner, A. (1962). An efficient method of estimating seemingly unrelated regressions and tests for aggregation bias. Journal of the American Statistical Association, 57, 348-368.

Zellner, A. (1963). Estimators for seemingly unrelated regression equations: Some exact finite sample results. Journal of the American Statistical Association, 58(304), 977-992.

Zhang, L. (2017). The knowledge spillover effects of FDI on the productivity and efficiency of research activities in China. China Economic Review, 42, 1-14. https://doi.org/10.1016/j.chieco.2016.11.001 